\begin{tabular}{|l|l|l||}
\hline \multicolumn{2}{|c|}{ PublisherInfo } \\
\hline \hline PublisherName & $:$ & BioMed Central \\
\hline \hline PublisherLocation & $:$ & London \\
\hline \hline PublisherImprintName & $:$ & BioMed Central \\
\hline \hline
\end{tabular}

\title{
Targeted destruction
}

\begin{tabular}{|l|l|l||}
\hline \multicolumn{2}{|c|}{ ArticleInfo } \\
\hline \hline ArticleID & $:$ & 4157 \\
\hline \hline ArticleDOI & $:$ & $10.1186 /$ gb-spotlight-20010724-01 \\
\hline \hline ArticleCitationID & $:$ & spotlight-20010724-01 \\
\hline \hline ArticleSequenceNumber & $:$ & 228 \\
\hline \hline ArticleCategory & $:$ & Research news \\
\hline ArticleFirstPage & $:$ & 1 \\
\hline \hline ArticleLastPage & $:$ & 2 \\
\hline \hline & & RegistrationDate : 2001-07-24 \\
ArticleHistory & $:$ & OnlineDate \\
\hline \hline ArticleCopyright & $:$ & BioMed Central Ltd2001 \\
\hline \hline ArticleGrants & $:$ & \\
\hline \hline ArticleContext & $:$ & 130592211 \\
\hline \hline
\end{tabular}




\section{Jonathan B Weitzman}

Email: jonathanweitzman@hotmail.com

Ubiquitination targets proteins for degradation by the sequential attachment of ubiquitin to lysine residues within the substrate molecule. Target specificity is determined by the E3 ubiquitin-protein ligases. One class of E3s consists of the heterotetrameric Skp1-Cullin-F box (SCF) complexes. The mammalian F-box protein $\beta$-TRCP directs the degradation of $\mathrm{I} \kappa \mathrm{B} \alpha$ by binding to a phosphorylated

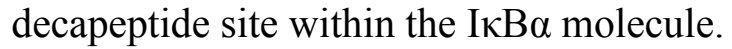

In the July 17 Proceedings of the National Academy of Sciences, Sakamoto et al. describe a method for artificially controlling protein degradation by exploiting characteristics of the SCF $\beta$-TRCP ubiquitin ligase (Proc Natl Acad Sci USA 2001, 98:8554-8559). To test the system they chose to target the methionine aminopeptidase (MetAP-2) protein which is bound by the angiogenesis inhibitor ovalicin (OVA). They synthesized an artificial compound called Protac-1 (proteolysis-targeting chimeric protein 1) which contained the I $\kappa \mathrm{B} \alpha$ phosphopeptide fused to ovalicin. They showed that Protac-1 can bind to MetAP-2 via the OVA moiety, and recruit it to the SCF $\beta$-TRCP complex, leading to its ubiquitination and subsequent degradation by the proteosome. The authors suggest that synthetic Protacs will serve as useful research tools and therapeutic agents to target ubiquitin-dependent degradation of a chosen target protein.

\section{References}

1. Ubiquitin-mediated proteolysis: biological regulation via destruction.

2. SCF and Cullin/Ring H2-based ubiquitin ligases

3. Proceedings of the National Academy of Sciences, [http://www.pnas.org]

4. Molecular recognition of angiogenesis inhibitors fumagillin and ovalicin by methionine aminopeptidase 2 . 